\title{
On the Difference or Equality of Information, Misinformation, and Disinformation: A Critical Research Perspective
}

\author{
Bernd Carsten Stahl \\ Centre for Computing and Social Responsibility, \\ De Montfort University, Leicester, UK
}

\author{
bstahl@dmu.ac.uk
}

\begin{abstract}
More and better information is often seen as a prerequisite for better management practices. It is the task of information systems to collect or create such information. These simple premises are problematic, however. One of the reasons for this is that the very concept of information is not clear. This paper discusses the notion of information as well as the apparently opposing notions of misinformation and disinformation from a critical research perspective. Starting with a discussion of the question of truth, the paper argues that there is no agreement on what truth is and, therefore, what information is. The critical approach provides a different way of understanding these issues. Critical research aims to change the status quo and lead to emancipation. Drawing on two of the most prominent theoreticians of critical research, Jürgen Habermas and Michel Foucault, the paper explores what truth and information can mean for critical research. The contribution of the paper is to extend the debate on information and truth beyond its typical confines and show to the researcher that these issues are not value-neutral; every commitment to a research approach is a value choice that the researcher makes and needs to reflect on.
\end{abstract}

Keywords: critical research in information systems, information, truth, Habermas, Foucault, emancipation

\section{Introduction}

The concept of information is clearly of central relevance for information systems (IS) research and practice. Many assume that information is central to managerial decision making and that more and higher quality information will lead to better outcomes. This assumption persists even though Ackoff (1967) has argued almost 40 years ago that it is misleading. One of the reasons for the longevity of this arguably naïve reliance on IS to produce more and better information is a

Material published as part of this journal, either on-line or in print, is copyrighted by the publisher of the Informing Science Journal. Permission to make digital or paper copy of part or all of these works for personal or classroom use is granted without fee provided that the copies are not made or distributed for profit or commercial advantage AND that copies 1) bear this notice in full and 2) give the full citation on the first page. It is permissible to abstract these works so long as credit is given. To copy in all other cases or to republish or to post on a server or to redistribute to lists requires specific permission and payment of a fee. Contact Editor@inform.nu to request redistribution permission. lack of conceptual clarity regarding the nature of "information".

There is no universally accepted theory or definition of truth. Yet, we have to use our everyday understanding of the term if we are to work with information. This leads to misunderstandings and problems. In this paper I address this conceptual problem from the point of view of critical research in information 
systems (CRIS). The paper starts with a review of the concept of information, emphasising the practical, involved and ethical nature of information. Another important characteristic of information is that it is held to be true. In order to demonstrate the problem of this belief, I briefly discuss the most prominent current theories of truth. The criterion of truth allows for the distinction between the concepts of information, misinformation, and disinformation. Having thus outlined the concept of information and some of its problems, the paper will give an overview of critical research in information systems. After defining CRIS, the paper introduces Jürgen Habermas and Michel Foucault, two of the main theorist of critical thought.,. For these two, truth and information have a different meaning from the one we traditionally associate with them. This means that, while one can still usefully distinguish between information and mis/dis-information, this can no longer be done from the objective perspective of the detached observer.

Based on the two competing theoretical foundations, the paper proceeds to analyse the meaning of information, misinformation, and disinformation in CRIS. Because of the different theories of truth, it is no longer possible to understand information as a correct description of a state of affairs. From the critical standpoint, one needs to consider question of consensus of those who are affected, but also questions of power and domination. Correspondingly, misinformation and disinformation change their character as well.

By the end of the paper the reader should have an appreciation of the fundamental problems of defining and determining information. The reader will furthermore develop a basic understanding of the value and approach of CRIS. While this approach does not offer any simple solutions, it is still immensely valuable because it allows us to frame questions differently and challenge the assumptions we usually take for granted. The paper demonstrates that what we often see as good and valid information may indeed be seen as disinformation and that the objectivist and positive perspective we usually associate with research can be misleading.

The paper leads to fundamental questions regarding the way we understand information, truth and research. It may therefore be uncomfortable reading for those who follow the established positivist paradigm without reflecting on these issues. It is not truly revolutionary, however, since the discourse on truth and disinformation has been ongoing for over 20 years (Hirschheim, 1985). It should be understood as one contribution to the difficult but necessary process of clarifying the philosophical issues upon which IS research and practice are built (Hirschheim, Klein \& Lyytinen, 1995). A lack of understanding and clarity of such issues is not only academically and intellectually unsatisfying but arguably part of the reason for the continually high failure rate in IS.

\section{Information}

This section deals with the conceptual basis of the paper by discussing the meaning of the concept of "information". After a brief review of the literature on information, some of the theories of truth are discussed, since information is usually deemed to be true. The last part of the section explores the meaning of misinformation, disinformation, and bias.

\section{Definitions of Information}

We allegedly live in an information society and possibly even in the information age. Information surrounds us, powers our economy, and makes us information workers. Given this ubiquity, one should hope that we actually know what information is. Like most ubiquitous terms, however, information is rather opaque. Brock \& Dhillon (2001), having done an in-depth review of the term, come to the conclusion that it is almost everything and anything and they liken it to the "ether" of the middle ages, which pervades everything but cannot be captured. In a classic 
definition, Wiener (1954, p. 17) states that "information is a name for the content of what is exchanged with the outer world as we adjust to it, and make our adjustment felt upon it", thus emphasising the processes involved in information sharing rather than the entity itself.

A typical approach to information in the field of IS is to compare it with the concept of data. Where data are the raw facts of the world, information is then data "with meaning". "When "data" acquires context-dependent meaning and relevance, it becomes information. Furthermore, we obviously expect information to represent valid knowledge on which users can rely for rational action" (Ulrich, 2001 p. 56). This relationship between data, information and meaning is frequently adopted (cf. Davenport \& Prusak, 1998; Walsham, 2001). It is also problematic. First, there is the problem that data are not simply brute facts of the world but that all data is already processed and gathered. Information thus cannot simply be the injection of meaning into data because data already has meaning, otherwise it would not be possible to perceive it (cf. Introna, 1997). The difference between data and meaning is thus a difference in the level and appreciation of meaning (cf. Floridi, 1999). Another problem of this definition is that it renders information completely idiosyncratic. Data that may hold meaning for you may be utterly meaningless to me. This would contradict the implicit assumption that information is more generally accessible, which is required for it to be processed it by machines.

This raises another problem, namely the relationship between information and technology. The reason why we are currently interested in information is that technology allows us to collect information (or data?) in previously unimaginable amounts. It can be processed automatically and checked for higher level patterns that would not be discernible without technology. This requires a new information infrastructure which, in turn, requires huge investments and therefore novel processes and procedures (Kahin, 1997). The transformation of information in a machinereadable format at the same time produces new problems, for example mobility and reproducibility (Straub \& Collins, 1990). The technical use of information also suggests that information must be machine-readable and thus quantifiable (Bloomfield \& Coombs, 1992). This returns us to the problem of meaning, because information, seen from a technical point of view, does not seem to offer a link to the concept of meaning as introduced earlier as central to information (Grim, Denis \& Kokalis, 2004).

Another approach to understanding information would be to look at its function. Information as meaningful data needs to have meaning to (human) agents. Such meaning is only relevant if information can affect actions or perceptions (cf. Mingers, 2001). Information without any consequences is arguably not information. If information has a direct influence on humans, then it will also have an ethical impact. Indeed, the ethical importance of information has been recognised for a long time (cf. Mason, 1986; Stichler, 1998; Wiener, 1954).

This discussion of information could be continued in a variety of directions. One could look at the disadvantages of information (e.g. information overload (cf. Postman, 1992)) or other related concepts such as facts, jargon, numbers, opinions (Brooke, 2002) or resulting developments, such as the informating nature of modern work (Zuboff, 1988). Extending the distinction of data and information, one could discuss further concepts such as knowledge, wisdom, or judgement (cf. French, 1990). The one aspect I will briefly elaborate on in the next section is that of truth.

\section{Information and Truth}

One strong assumption about information is that it is true. If it were not true, then the meaning associated with it would be wrong or misleading. Untrue information can also not inform perception or action. De George (2003) distinguishes between data and information precisely because data contains no claim to truth whereas information does. 
This raises the difficult question what it means for a statement to be true. I will not dwell on these questions too long. However, it is important to briefly think about the criteria we accept for something to be held true or false because the critical approaches to be introduced later will differ greatly in this respect from the common sense understanding we typically use.

Truth is a property of a statement. A sentence or proposition can be true or false. When do we say a statement is true? A typical answer would be: "A statement is true if it describes a state of the world as it is." Or, we could rephrase, a statement is true if it corresponds with the way the world is. We therefore call this the correspondence theory of truth (Feyerabend, 1980; McCarthy, 1992). The correspondence theory would appear to be what has been called the "natural attitude". Humans are socialised into believing that one can objectively perceive and make true statements about an external reality. The theory is problematic, however. The most serious problem it has to contend with, and which even strong supporters cannot overcome, is its inability to explain how an external reality can be equal to a mental representation (Khlentzos, 2004).

Alternative accounts of truth include the pragmatic, consensus, and coherence approaches. For adherents of the pragmatic view, a statement is true if it contributes to a desired outcome (Rorty, 1982). A consensus view of truth is based on the conviction that the criterion for the truth of a statement is the consensus of all (or all relevant or all informed) individuals or parties (Rorty, 1996; Apel, 1994). Finally, a statement can be seen as true if it conforms to a variety of other statements and does not contradict other known true statements. Such an approach is typical for formal languages or mathematics.

All theories of truth have consequences for the way we create true statements, for what counts as evidence and how we collect it (Gergen, 1999). They are closely linked to our understanding of the nature of being (ontology) but also to our view of right and wrong (ethics) or the nature of humankind (anthropology). These implications, which are often discussed under the heading of "paradigm" go far beyond what we can discuss in this brief paper (Orlikowski \& Baroudi, 1991; Varey, Wood-Harper \& Wood, 2002). The question of truth is important in this essay because it has to do with the difference between information and mis-/dis-information. At the same time, the critical approach does not subscribe to a traditional correspondence view of truth, thus necessitating different criteria for determining the difference between information and mis-/disinformation.

\section{Mis- / and Dis-Information}

The most important distinction between information and mis-information and dis-information is the question of truth. Where information is true, misinformation or disinformation are untrue. I follow the definition of the Oxford English Dictionary (http://www.oed.com/ accessed 27.10.05) and use misinformation to denote "wrong or misleading information". Disinformation is also wrong information but unlike misinformation, it is a known falsehood. The OED defines disinformation as "the dissemination of deliberately false information" and refers specifically to wrong information supplied by governments. In this paper I will continue to distinguish between misinformation as accidental falsehood and disinformation as deliberate falsehood. Bias, as unacknowledged personal conviction, can probably be seen as a reason for misinformation. I will therefore disregard the concept in this paper.

\section{The Critical Approach}

Since the unique contribution of the paper is to discuss the concepts of mis-/ dis-information from a critical perspective, I now briefly introduce the idea of critical research in information systems. In the first section I give a general overview of the debate on critical research and subsequently I 
introduce the two scholars who are most widely cited in critical research in IS, Habermas and Foucault.

\section{The Concept of Critical Research in IS}

Critical research is a concept that is not clearly defined but that is probably best understood as an umbrella that covers a range of different ideas (cf. Brooke, 2002). These ideas have some characteristics in common. Discussing the commonalities allows us to come to a sort of definition of critical research, even though it should be noted that this definition cannot be comprehensive because the range of different approaches is to diverse.

In the field of information systems, critical research is often seen as a "paradigm" (Chua, 1986; Orlikowski \& Baroudi, 1991; Trauth, 2001). Loosely based on Kuhn's (1996) notion of a paradigm, this means that critical research is a composition of a variety of aspects, including ontology, epistemology, an assumption about the nature of humans and society and others. The notion of a paradigm is in many respects misleading, which is why I suggest concentrating on the following characteristics of critical research: intention, topics, theory, and methodology. Critical research has its roots in the Marxist critique of capitalism and it is based on the perception that the current status quo is unjust. It can therefore be characterised by its intention to change social realities (Alvesson \& Deetz, 2000; Ngwenyama \& Lee, 1997) and favour the disadvantaged (Mingers, 1992). Critical research can thus never be purely descriptive but is intrinsically normative and based on values (Walsham, 1993). Another way of saying this is that "a critical stance is focused on what is wrong with the world rather than what is right" (Walsham, 2005).

The concept most frequently used to represent the critical intention to change social realities is "emancipation" (Alvesson \& Willmott, 1992; Howcroft \& Trauth, 2004; McAulay, Doherty \& Keval, 2002; McGrath, 2005). Critical research aims to emancipate those who are alienated because of the current structure of society and production, those who are excluded from the discourses that shape our society. Emancipation stands for the attempt to help people to achieve their potential (Klein \& Huynh, 2004). It has an organisational / societal as well as a psychological dimension (Hirschheim \& Klein, 1994). This intention to emancipate individuals is sometimes also expressed in terms of empowerment (Lyytinen \&Hirschheim, 1988; CecezKecmanovic, 2001).

The critical intention to change reality and emancipate people leads critical researchers toward the choice of certain topics. These are topics which promise the researcher to identify issues of suppression and alienation and allow them to make a difference. They are typically interested in social structures or organisational configurations that express ideologies and reify discourses. The purpose of research is then to expose ideologies and open up discourses by introducing new arguments. The range of topics that allow critical researchers to do this is wide. They range from theoretical and abstract, such as the questions of identity (Forester, 1992) or rationality in business / capitalism (Cecez-Kecmanovic, Janson \& Brown, 2002; Levy, Alvesson \& Willmott, 2003), to social and legal, such as the problem of commodification of information and humans (Brooke, 2002; Knights \& Willmott, 1999) or gender in IS (Kvasny, Greenhill \& Trauth), to concrete organisational research. One topic that most critical research is concerned with because it is deeply linked to suppression and emancipation is the issue of power (Brooke, 2002).

In order to realise the emancipatory intention, critical research tends to follow certain methodologies. However, there is no clear and unambiguous link between the critical intention and a specific research approach (Avgerou, 2005; McGrath, 2005). Current critical research in IS does seem to be close interpretive research in the choice of research methods typically used. This may be explained by the fact that critical researchers usually believe that reality is socially and linguistically structured and that, therefore, methods that emphasise the importance of language 
are important. Much critical research is also of a purely conceptual nature. There is nevertheless no principal reason why critical research could not use positivist and quantitative ways of doing research.

This very brief introduction to critical research in IS cannot be comprehensive. It cannot address most of the fundamental problems of critical research. How do we know whether someone is emancipated? Can we force emancipation on individuals who are not interested? Can critical research actually achieve the critical intention or is it just abstract talk in the ivory tower (Oates, 2004)? And, maybe most importantly, is critical research just another partial ideology which competes with a range of others and has no claim to universal validity (Wilson, 1997)? I have to leave those question open and now briefly introduce the important theoretical side of critical research by discussing the work of the two most widely cited scholars in CRIS: Michel Foucault and Jürgen Habermas.

\section{Michel Foucault}

A good starting point for an introduction to Foucault's work is probably his "order of discourse" (1971), where he describes the overarching themes of his prior publications and outlines future research. The concept of discourse is central to his work. Discourses shape social reality and individual perceptions. His main interest is in how discourses are formed, controlled, distributed, and which mechanisms regulate participation. He is particularly interested in how certain individuals or topics are excluded from discourses. His different works concentrate on different aspects of exclusion from discourse. Mechanisms and procedures of exclusion include insanity, certain views of sexuality, and bodily discipline. Another means of controlling discourses are conditions and perceptions of discourses, such as the Western myth of free and open discourses. And while Western democracies pretend to honour open discourses, Foucault contends that, in reality, they fear it. These critical observations regarding discourses render the allegedly peaceful mechanisms of discourse an expression of (tacit) violence.

Foucault does not try to promote a better form of discourse. His aim is to give an open description of how discourses are shaped (Knights \& Morgan, 1991). The way he does this is to describe how configurations of discourses have developed. He uses an archaeological approach, which he also describes in terms of genealogy, which means that he analyses the history of discourses. A concept closely linked to Foucault's work is power. Discourses are the means by which power is exerted but they are also subject to power constellations (Foucault, 1976). The concept of power in Foucault's work is very wide. Power is not just the ability to enforce one's will against others but it is a wide range of influences (Wong, 2002). Power is created and perpetuated through discipline. Foucault's possibly most widely-read book, "Discipline and Punish" (1975) discusses how discipline of the docile body is used to create discourses and social institutions.

Power and discourse are linked by the idea of regimes of truth (McGrath, 2003). These regimes of truth refer to the collection of statements that are considered true and acceptable within a particular discourse. Foucault's research concentrates on how such regimes of truth are constituted. Regimes of truth are a result of power constellations because power allows the establishment of truths. Again, however, this is not a one-way relationship. Regimes of truth can also undermine power relationships.

This idea of regimes of truth is highly relevant to the current paper. It shows that for Foucault truth is not a matter of correspondence between statement and external reality but has to do with negotiations in discourses, which, in turn, are shaped by power relationships and physical and mental discipline. Truth is not given and stable but fluid. Foucault does not want to educate us what truth really is or should be. His interest is in describing how regimes of truth come into being. 


\section{Jürgen Habermas}

Habermas, probably the most widely cited scholar in CRIS, follows a very different approach to criticality. (For a more complete introduction to Habermas's ideas and their application in IS cf Klein \& Huynh, 2004 or Janson \& Cecez-Kecmanovic, 2005). For Habermas, too, the concept of discourse is central to critical thinking. It has, however, a vastly different meaning. Habermas is a successor of the idea of enlightenment but he sees that a Kantian reliance on individual reason is doomed to failure. Being inspired by the continental European philosophical tradition but also by Anglo-American philosophy of language, Habermas realises what he sometimes calls the "linguistic turn". This means that reason is no longer seen as an individual property but is moved to a collective realm. The individual human being lives within a "life-world", which means that we all have our individual perceptions of reality and truth. However, these life-worlds are not completely idiosyncratic because they are constituted through socialisation and upheld through communication.

The idea of communication is thus central to Habermas' work and his theory of communicative action (TCA) (Habermas, 1981a, 1981b) is arguably his main publication. Communicative action is one possible mode of action; it is the mode that takes the other serious and therefore aims to understand and communicate with the other. According to the TCA, when we communicate with others, all speech acts carry three validity claims: truth, normative rightness, and authenticity. This means that all utterances imply that the speaker speaks the truth, that the statement is normatively justified, and that the speaker is sincere in what she says. These are not empirical descriptions but transcendental to communication, which means that without the assumptions of truth, rightness, and authenticity, we would not need to be able to communicate.

In many cases, participants in communication will not agree on validity claims and will doubt whether statements are indeed valid. This is where the concept of discourse plays a role in Habermas's writing. Discourses stand for the type of communication where contentious validity claims can be discussed. They imply that the speakers recognise that they interact under the conditions of the ideal speech situation, a counterfactual collection of conditions, which include the ability of everyone affected to participate in the discourse, the absence of overt power differences, the practical and linguistic competencies of participants (Habermas, 1996). The idea of the ideal speech situation is that the best argument will convince the community of discourse and lead to a consensus on the validity claim in question.

With regards to the question of truth, one can state that truth is of central importance for Habermas. However, it is not a correspondence idea of truth that Habermas uses but a consensus theory. A statement can be seen as true, if it is accepted by all competent members of the community of discourse (Habermas, 1998). Truth claims that are contentious are addressed by opening a discourse, not by establishing a reference to the external world. Of course, it is conceivable that the discourse will take up questions of correspondence, but these are not the criterion for truth.

\section{The Relationship between Habermas and Foucault}

The brief introduction above cannot do justice to either Habermas or Foucault. It should suffice, however, to convince the reader their approaches offer a different understanding of truth and thus of information. There is a complex debate to be had what the relationship between Habermas and Foucault is (cf. Ashenen \& Owen, 1999; Kelly, 1994; Stahl, 2004). Fortunately, we do not have to make a decision here whether they are compatible. It can safely be said that they are both recognised as important reference scholars in the debate on critical research in IS. Both share the critical intention to change social reality, which is perceived as not being just and desirable. While emancipation is an express goal of Habermas's, Foucault would arguably be more sceptical 
about the possibility of achieving emancipation. His genealogical work can nevertheless be understood as an expression of the desire to help people understand the situation they find themselves in and thus to facilitate an improvement in their status quo.

Having established what critical research in IS means and which theoretical bases there are, I now return to the central question of the paper: what is information / disinformation / misinformation from the point of view of critical theory?

\section{Mis- / Dis- Information in Critical Research}

This section combines the above discussions of information and critical research. It concentrates on the nature of misinformation and disinformation as seen from a critical viewpoint and explore the difference with regards to information from a Habermasian and Foucauldian angle.

\section{Truth in Critical Research}

For a critical researcher, truth can never be an objective description of an external reality. All perception is always value-laden and based on individual and collective prejudices. Following the hermeneutic tradition, critical researchers in IS tend to agree that prejudices cannot be overcome (Gadamer, 1990). Instead, the purpose of research is to expose them and render them open to discursive analysis. This raises serious problem for a critical epistemology. How can we know what is true if all truth claims can always be contested? And how can critical theory claim to be true, if it fundamentally doubts the existence of eternal truths? The short answer to this is that critical research has to emphasise reflexivity. That means that critical research must question its own assumptions and foundations. Only by remaining open to constant questioning can it be possible to overcome the dilemma of scepticism. (The dilemma of scepticism is that it doubts the existence of truth and thus cannot be true.) And, indeed, an emphasis on reflexivity is central to critical research (Cecez-Kecmanovic, 2001; Steffy \& Grimes, 1992; Waring, 2004).

Another important aspect of the understanding of truth in CRIS is that truth cannot be value neutral. It is impossible to divide truth claims from normative claims. Following Habermas, one can say that every speech act simultaneously promotes different validity claims, which can be separated for the purpose of analysis but in practical discourses always exist side by side. A presumably value-neutral statement such as "the Technology Acceptance Model (TAM) offers a good description of ICT user behaviour" is not really value-neutral. It implies that the speaker has a right to say this, and that saying it does not limit anyone's rights. It assumes that objective descriptions are possible and good, which is a value statement. Alternative descriptions of reality are curtailed because the assumed truth of the statement puts the onus on the listener to believe it and use TAM as a description of reality. All of this is not meant to show that this is an immoral statement but rather that it is not value-free.

Truth can also be used as an ideology. The worst form of ideology is that which has been recognised as truth and is therefore no longer open to debate. If we accept as true, for example, that women are inferior to men, then there is no need to debate the statement. Truths, which are generally accepted, are therefore the strongest form of ideology. And they are also closely linked to power. If it is true that managers are rational humans who can recognise the needs of the organization and maximise the utility, then there is no need to question the status of managers in the organisation or the role of commercial entities in society. Truth thus cements power and, at the same time, power helps establish truth. A look at popular discourse about companies and their role in society or the role of ICT in organisations shows that there are numerous "truths", which stabilise the status quo without there being strong evidence to support them. Among them there is the assumption that economic growth is the panacea to most of society's problems, that economic 
rationality is the best way to approach questions of distribution, or that the use of ICT will improve organisational processes from commerce and government to education.

Such objectification and reification of ideologies is what critical research aims to explore and overcome. With regards to ICT, this means that it is important to discuss its role and uses. ICT does not determine its use but a look at current technology shows that its uses for liberating purposes are rare, whereas the large systems used by government and businesses tend to be about exerting control and power. Ackoff (1967, p. 150), in his paper which inspired the discussion of information and mis/dis-information, said this quite clearly: "Information systems are subsystems of control systems."

\section{Misinformation and Disinformation in CRIS}

If we go back to the definition of information, then a relevant aspect is that it makes a difference, that it "in-forms" people and helps them orientate themselves. Given that critical research is interested in emancipation, one can say that from the perspective of CRIS information is what helps emancipate humans, whereas misinformation and disinformation alienates and

disempowers. To address this, CRIS can try to point out where information as well as technology hide and propagate ideology. A nice example of this is provided by Introna (1997) who points out that the information provided by MIS is best described as a status symbol. It allows the user (manager) to lay a claim to rationality, which in our society is a legitimization for the exertion of power. This would not be so bad if it did not mean that it legitimizes the manager to make decisions that can alienate others. And it would also be acceptable if the relative nature of such truth claims were clearer. However, the current truth discourse that tries to find universal truths easily turns in to (cultural) imperialism (Gergen 1999).

To return to the difference between misinformation and disinformation, one can say that for a critical researcher misinformation are such claims that inadvertently lead to alienation whereas disinformation are claims which the originator knows to be alienating but nevertheless proposes.

From a Habermasian perspective misinformation is not problematic. It is simply information that is contentious and that therefore will be analysed in a discourse. The person claiming truth will have to explain the reasons for the claim and will have to answer critique. All of this can be done within the framework of communicative action where people recognise each other as dignified beings and are willing to take each other seriously. Disinformation is more problematic. Since it is information that deliberately alienates or disempowers people, the speaker shows a disregard for the other who is disempowered. This means that she is not interacting in communicative mode but in what Habermas calls "strategic" mode, where others are used as means to the speaker's ends. From a Habermasian perspective, this would still be subject to discourse because one could point out to the speaker that she is self-contradictory. The problem is, however, that she may simply not care. This is where critical research becomes problematic. The hope of current critical research is that by exposing ideology and false claims, these will be rectified. It does not offer any guarantee, however, that this will happen. When disinformation is exposed as such and still not changed, then critical research will have reached its limits and need to interact with other social institutions such as politics or the law to stimulate change.

The distinction between misinformation and disinformation would look different from a Foucauldian viewpoint. Foucault is much more sceptical about any truth claims than Habermas. A Foucauldian could argue that the distinction between misinformation and disinformation is artificial because it seems to presuppose the existence of a universal truth and the selfreflectiveness of the speaker to know her own intentions when speaking. Both may be doubtful. A further problem would be that the idea of emancipation is much less clear and that it is not obvious whether emancipation is not a particular ideology itself. 
The Foucauldian approach would therefore be to undertake a genealogy of information and try to understand why some statements are believed to be true or false and why individuals would form propositions that can be construed as false. The emphasis in such a genealogy would be on questions of power and bodily discipline. How are we socialised in order for us to accept certain truths and falsehoods? This Foucauldian approach does not offer any hope to come to a clear distinction between truth and untruth, between information and misinformation. However, it seems to be carried by an implicit hope that there are better (more empowering) accounts of the world and worse ones. Otherwise there would be little point in undertaking a genealogy.

\section{Conclusion}

This paper should have clarified that, from the point of view of critical research, the distinction of information, misinformation, and disinformation is problematic. It is closely linked to the question of truth and we should admit that there is no universally accepted theory of truth. The critical approach will help scholars to widen their understanding of issues and question their own work. Choosing to do critical research is not a value-neutral stance but requires the researcher to actively reflect on their assumption. It is based on a desire to promote emancipation rather than work in systemic imperatives.

The paper will also have shown that critical research does not offer any easy answers. By discussing the two competing theoretical approaches of Habermas and Foucault, it has shown that even within critical research there is no unanimous answer to what information is and whether we can detect and address misinformation or disinformation. However, it should also have shown that critical research provides us with ways of thinking about truth and what we hold to be true or false. It stresses the fact that truth is not a natural occurrence and that it is worthwhile to think about where it comes from and who promotes it or benefits from it.

One argument that the paper certainly does not promote is that critical researchers become the gatekeepers of truth and information. This would only substitute one type of ideology for another. Neither does the paper suggest that there is no truth, which would leave it open to the charges of being relativistic and self-contradictory. Instead, the practical lesson to be learned from the above discussions is that we need to be very careful with regards to truth claims and realize that truth is always open to debate. This means that there is no clear and unambiguous dividing line between information and misinformation. A statement that can serve as useful and clear information when uttered by $\mathrm{A}$ in context $\mathrm{B}$ can become an outright lie with political intentions when uttered by person $\mathrm{C}$ in context $\mathrm{D}$. The only thing that can be done in the light of this uncertainty of truth and information is to keep an open mind and remain open to discourses and new arguments.

Finally, I hope that this paper will stimulate debate and individual reflection about the critical approach. Researchers should realise that there is no choice between value-laden critical research and objective non-critical (positivist, interpretivist,...) research. Instead, the choice not to engage in critical research is as much a value choice as the choice to do it. Choosing not to engage in a critical way is fundamentally a conservative stance. Researchers are of course free to make such a choice but they should be aware of it and they should ask themselves whether their time is better spent thinking about emancipation or stabilising the current system. 


\section{References:}

Ackoff, R. L. (1967). Management misinformation systems. Management Science, 14(4), 147 - 156.

Alvesson, M. \& Deetz, S. (2000). Doing critical management research. London: SAGE

Alvesson, M. \& Willmott, H. (1992). On the idea of emancipation in management and organization studies. Academy of Management Review, 17(3), 432 - 464.

Apel, K-O. (1994). Die ökologische Krise als Herausforderung für die Diskursethik. [The Ecological Crisis as a Challenge for Discourse Ethics] In D. Böhler (Ed.), Ethik für die Zukunft. Im Diskurs mit Hans Jonas [Ethics for the Future: A Discourse with Hans Jonas] (369-404). München: C.H. Beck.

Ashenden, S. \& Owen, D. (Eds.). (1999). Foucault contra Habermas: Recasting the dialogue between genealogy and critical theory. London: SAGE.

Avgerou, C. (2005). Doing critical research in information systems: Some further thoughts. Information Systems Journal, 15, 103 - 109.

Bloomfeld, B. P. \& Coombs, R. (1992). Information technology, control, and power: The centralization and decentralization debate revisited. Journal of Management Studies, 29(4), 459 - 484.

Brock, F. J.\& Dhillon, G. S. (2001). Managerial information: The basics. Journal of International Information Management, 10(2), 45 - 59.

Brooke, C. (2002). Critical perspectives on information systems: An impression of the research landscape. Journal of Information Technology, 17, 271 - 283.

Cecez-Kecmanovic, D. (2001). Doing critical IS research: The question of methodology. In E. Trauth (Ed.), Qualitative research in IS: Issues and trends (141 - 162). Hershey: Idea Group Publishing.

Cecez-Kecmanovic, D., Janson, M., \& Brown, A. (2002). The rationality framework for a critical study of information systems. Journal of Information Technology, 17, 215 - 227.

Chua, W. F. (1986). Radical developments in accounting thought. The Accounting Review, 61(4), $601-$ 632.

Davenport, T. H. \& Prusak, L. (1998). Working knowledge: How organizations manage what they know. Boston: Harvard Business School Press.

De George, R. T. (2003). The ethics of information technology and business. Oxford: Blackwell.

Feyerabend, P. K. (1980). How to be a good empiricist - A plea for tolerance in matters epistemological. In H. Morick (Ed.), Challenges to empiricism (164 - 193). London: Methuen.

Floridi, L. (1999). Philosophy and computing: An introduction. London: Routledge.

Forester, J. (1992). Critical ethnography: On fieldwork in a Habermasian way. In M. Alvesson \& H. Willmott (Eds.). Critical management studies (46-65). London: SAGE.

Foucault, M. (1971). L'ordre du discours. [English Translation: The Order of Discourse] Paris: Gallimard.

Foucault, M. (1975). Surveiller et punir: Naissance de la prison. [English Translation: Discipline and Punish the birth of the prison / Michel Foucault / translated from the French by Alan Sheridan, Harmondsworth : Penguin, 1979] Paris: Gallimard.

Foucault, M. (1976). Histoire de la sexualité I: La volonté de savoir [The history of sexuality / (by) Michel Foucault / translated from the French by Robert Hurley. Vol.1. An introduction. London : Allen Lane, 1979] Paris: Gallimard.

French, J. A. (1990). The business knowledge investment: Building architected information. Englewood Cliffs, New Jersey: Yourdon Press. 
Gadamer, H-G. (1990). Wahrheit und Methode - Grundzüge einer philosophischen Hermeneutik (6th edition). [Truth and method /2nd rev. ed. / translation revised by Joel Weinsheimer and Donald G. Marshall, London : Sheed and Ward, 1989] Tübingen: J.C.B. Mohr (Paul Siebeck).

Gergen, K. J. (1999). An invitation to social construction. London: Sage.

Grim, P., Denis, P. St. \& Kokalis, T. (2004). Information and meaning: Use-based models in arrays of neural nets. Minds and Machines, 14(1), 43 - 66.

Habermas, J. (1981a). Theorie des kommunikativen Handelns - Band I. [The theory of communicative action / Vol.1 : Reason and the rationalization of society, Oxford : Polity Press, 1991,] Frankfurt a. M.: Suhrkamp.

Habermas, J. (1981b). Theorie des kommunikativen Handelns - Band II. [The theory of communicative action / Jürgen Habermas / translated by Thomas McCarthy. - Vol.2 : Lifeworld and system,

Cambridge : Polity, 1987] Frankfurt a. M.: Suhrkamp.

Habermas, J. (1996). Die Einbeziehung des Anderen - Studien zur politischen Theorie. [The Inclusion of The Other (MIT Press, 1998)] Frankfurt a. M : Suhrkamp.

Habermas, J. (1998). Faktizität und Geltung: Beiträge zur Diskurstheorie des Rechts und des demokratischen Rechtsstaats. [Between Facts and Norms. Contributions to a Discourse Theory of Law and Democracy (Polity Press, 1996)] Frankfurt a. M.: Suhrkamp.

Hirschheim, R. A. (1985). Information systems epistemology: An historical perspective. In E. Mumford, R. Hirschheim, G. Fitzgerald, \& T. Wood-Harper (Eds.). Research Methods in Information Systems (IFIP 8.2 Proceedings), 13-36. Amsterdam: North-Holland.

Hirschheim, R. \& Klein, H. K. (1994). Realizing emancipatory principles in information systems development: The case for ETHICS. MIS Quarterly, 18(1), 83 - 109.

Hirschheim, R., Klein, H. K. \& Lyytinen, K. (1995). Information systems developing and data modeling: Conceptual and philosophical foundations. Cambridge: Cambridge University Press.

Howcroft, D. \& Trauth, E. M. (2004). The choice of critical information systems research. In B. Kaplan, D. P. Truex, D. Wastell, A. T. Wood-Harper, \& J. DeGross (Eds), Information Systems Research: Relevant Theory and Informed Practice (IFIP 8.2 Proceedings), 196-211. Dordrecht: Kluwer.

Introna, L. (1997). Management, information and power: A narrative of the involved manager. London: MacMillan.

Janson, M. \& Cecez-Kecmanovic, D. (2005). Making sense of e-commerce as social action. Information Technology \& People, 18(4), $311-342$.

Kahin, B. (1997). The U.S. national information infrastructure initiative: The market, the web, and the virtual project. In B. Kahin \& E. J. Wilson (Ed.), National Information Infrastructure Initiatives Vision and Policy Design (150-189). Cambridge, Massachusetts, and London, England: MIT Press.

Kelly, M. (Ed.). (1994). Critique and power: Recasting the Foucault / Habermas debate (17-46). Cambridge, Massachusetts / London: MIT Press.

Khlentzos, D. (2004). Naturalistic realism and the antirealist challenge. Cambridge, Massachusetts: The MIT Press.

Klein, H. K. \& Huynh, M. Q, (2004). The critical social theory of Jürgen Habermas and its implications for IS research. In J. Mingers \& L. Willcocks (Eds.), Social theory and philosophy for information systems (157-237). Chichester: Wiley.

Knights, D. \& Morgan, G. (1991). Corporate strategy, organizations, and subjectivity: A critique. Organization Studies, 12(2), $251-273$.

Knights, D. \& Willmott, H. (1999). Management lives: Power and identity in organizations. London: Sage. 
Kuhn, T. S. (1996). The structure of scientific revolutions (3rd edition). Chicago and London: The University of Chicago Press.

Kvwasny, L., Greenhill, A., \& Trauth, E. (2005). Giving voice to feminist projects in MIS research. International Journal of Technology and Human Interaction, 1(1), 1 - 18.

Levy, D. L.; Alvesson, M. \& Willmott, H. (2003). Critical approaches to strategic management. In M. Alvesson \& H. Willmott, (Eds.), Studying management critically $(92-110)$. London: SAGE.

Lyytinen, K. \& Hirschheim, R. (1988). Information systems as rational discourse: An application of Habermas theory of communicative action. Scandinavian Journal of Management, 4(1/2), $19-30$.

Mason, R. O. (1986). Four ethical issues of the information age. MIS Quarterly, 10, 5 - 12.

McAulay, L., Doherty, N., \& Keval, N. (2002). The stakeholder dimension in information systems evaluation. Journal of Information Technology, 17, $241-255$.

McCarthy, T. (1992). Philosophy and social practice: Avoiding the ethnocentric predicament. In A. Honneth, T. McCarthy, C. Offe, \& A. Wellmer, Philosophical interventions in the unfinished project of enlightenment (241 - 260). Cambridge, Massachusetts \& London: MIT Press.

McGrath, K. (2003). In a mood to make sense of technology: A longitudinal study of discursive practices at the London ambulance service. In E. Wynn, E. Whitley, M. D. Myers, \& J. DeGross, (Eds.), Global and Organizational Discourse About Information Technology (Ifip Tc8/Wg8.2 Conference, 485 - 506). Dordrecht: Kluwer Academic Publishers.

McGrath, K. (2005). Doing critical research in information systems: A case of theory and practice not informing each other. Information Systems Journal, 15, 85 - 101.

Mingers, J. (1992). Technical, practical and critical OR - Past, present and future? In M. Alvesson \& H. Willmott (Eds.), Critical management studies (90 - 113). London: SAGE.

Mingers, J. (2001). Embodying information systems: The contribution of phenomenology. Information and Organization, 11(2), $103-128$.

Ngwenyama, O. K. \& Lee, A. S. (1997). Communication richness in electronic mail: Critical social theory and the contextuality of meaning. MIS Quarterly, 21(2), $145-167$.

Oates, B. J. (2004). Action research: Time to take a turn? In B. Kaplan, D. P. Truex, D. Wastell, A. T. Wood-Harper, \& J. DeGross (Eds.), Information Systems Research: Relevant Theory and Informed Practice (IFIP 8.2 Proceedings), 315 - 333. Dordrecht: Kluwer.

Orlikowski, W. J. \& Baroudi, J. J. (1991). Studying information technology in organizations: Research approaches and assumptions. Information Systems Research, 2(1), $1-28$.

Postman, N. (1992). Technopoly - The surrender of culture to technology. New York: Vintage Books.

Rorty, R. (1982). Consequences of pragmatism (Essays 1972 - 1980) [5 ${ }^{\text {th }}$ printing 1991]. Minneapolis: University of Minnesota Press.

Rorty, R. (1996). On moral obligation, truth, and common sense. In J. Niznik, \& J. T. Sanders (Eds.), Debating the state of philosophy - Habermas, Rorty and Kolakowski. Westport, Connecticut / London: Praeger.

Stahl, B. C. (2004). Whose discourse? A comparison of the Foucauldian and Habermasian concepts of discourse in critical IS research. In Proceedings of the Tenth Americas Conference on Information Systems, New York, 06 to 08 August 2004, 4329 - 4336

Steffy, B. D. \& Grimes, A. J. (1992). Personnel / organization psychology: A critique of the discipline. In M. Alvesson \& H. Willmott (Eds.), Critical management studies (181 - 201). London: SAGE.

Straub, Dd W. \& Collins, R. W. (1990). Key information liability issues facing managers: Software piracy, proprietary databases, and individual rights to privacy. MIS Quarterly, 14, 143-156. 
Stichler, R. N. (1998). Ethics in the information market. In R. N. Stichler \& R. Hauptman (Eds.), Ethics, information and technology: Readings (169 - 183). Jefferson, North Carolina: MacFarland.

Trauth, E. (2001). Choosing qualitative methods in IS research: Lessons learned. In E. Trauth (Ed.), Qualitative Research in IS: Issues and Trends (271 - 287). Hershey: Idea Group Publishing.

Ulrich, W. (2001). A philosophical staircase for information systems definition, design, and development. Journal of Information Technology Theory and Application, 3(3), 55 - 84.

Varey, R. J., Wood-Harper, T., \& Wood, B. (2002). A theoretical review of management and information systems using a critical communications theory. Journal of Information Technology, 17, $229-239$.

Walsham, G. (1993). Interpreting information systems in organizations. Chichester: Wiley

Walsham, G. (2001). Making a world of difference - IT in a global context. Chichester: Wiley

Walsham, G. (2005). Learning about being critical. Information Systems Journal, 15, 111 - 117.

Waring, T. (2004). From critical theory into information systems practice: A case study of a payrollpersonnel system. In B. Kaplan, D. P. Truex, D. Wastell, A. T. Wood-Harper, \& J. DeGross (Eds.), Information Systems Research: Relevant Theory and Informed Practice (IFIP 8.2 Proceedings), 556575. Dordrecht: Kluwer.

Wiener, N. (1954). The human use of human beings - Cybernetics and society. Garden City, New York: Doubleday Anchor Books.

Wilson, F. A. (1997). The truth is out there: the search for emancipatory principles in information systems design. Information Technology \& People, 10(3), 187 - 204.

Wong, J. (2002). Sapere Aude: Foucault and understanding values. Presented at the 20th Society for Applied Philosophy Conference, Mansfield College, Oxford, UK, June 28-30, 2002

Zuboff, S. (1988). In the age of the smart machine: The future of work and power. New York: Basic Books

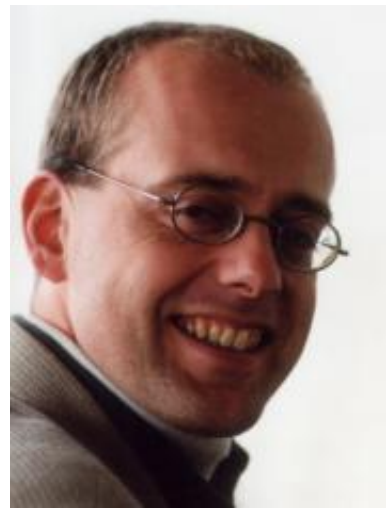

\section{Biography}

Bernd Carsten Stahl is a Senior Lecturer in the Faculty of Computing Sciences and Engineering and a Research Associate at the Centre for Computing and Social Responsibility of De Montfort University, Leicester, UK. His interests cover philosophical issues arising from the intersections of business, technology, and information. This includes the ethics of computing and critical approaches to information systems. $\mathrm{He}$ is the Editor-in-Chief of the International Journal of Technology and Human Interaction.

See: http://www.cse.dmu.ac.uk/ bstahl/ 